ҚАЗАҚСТАН РЕСПУБЛИКАСЫ

ҰЛТТЫҚ ҒЫЛЫМ АКАДЕМИЯСЫНЫН

АБАЙ АТЫНДАҒЫ ҚАЗАҚ ҰЛТТЫҚ

ПЕДАГОГИКАЛЫҚ УНИВЕРСИТЕТІНІҢ

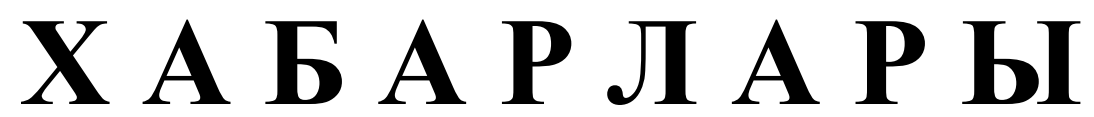

\section{ИЗВЕСТИЯ}

НАЦИОНАЛЬНОЙ АКАДЕМИИ НАУК РЕСПУБЛИКИ КАЗАХСТАН

КАЗАХСКИЙ НАЦИОНАЛЬНЫЙ

ПЕДАГОГИЧЕСКИЙ УНИВЕРСИТЕТ ИМ. АБАЯ

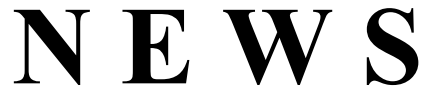

OF THE NATIONAL ACADEMY OF SCIENCES OF THE REPUBLIC OF KAZAKHSTAN

ABAY KAZAKH NATIONAL PEDAGOGICAL UNIVERSITY

ҚОҒАМДЫҚ ЖӘНЕ ГУМАНИТАРЛЫҚ ҒЫЛЫМДАР СЕРИЯСЫ

СЕРИЯ ОБЩЕСТВЕННЫХ И ГУМАНИТАРНЫХ НАУК

$\checkmark$

SERIES OF SOCIAL AND HUMAN SCIENCES

$$
5 \text { (321) }
$$

КЫРКУЙЕК - КАЗАН 2018 ж.

СЕНТЯБРЬ - ОКТЯБРЬ 2018 Г.

SEPTEMBER - OCTOBER 2018

1962 ЖЫЛДЫҢ ҚАНТАР АЙЫНАН ШЫҒА БАСТАҒАН

ИЗДАЕТСЯ С ЯНВАРЯ 1962 ГОДА

PUBLISHED SINCE JANUARY 1962

ЖЫЛЫНА 6 РЕТ ШЫҒАДЫ

ВЫХОДИТ 6 РАЗ В ГОД

PUBLISHED 6 TIMES A YEAR 
Ба с ре дактор

ҚР ҰҒА кұрметті мүшесі

Балықбаев Т.O.

Р е д а ц и я а лқ а сы:

экон. ғ. докторы, проф., ҚР ҰҒА академигі Баймұратов У.Б.; тарих ғ. докторы, проф., ҚР ҰҒА академигі Байпақов К.М.; филос. ғ.докторы, проф., ҚР ҰҒА академигі Есім Г.Е.; фил. ғ. докторы,, проф., ҚР ҰҒА академигі Қирабаев С.С.; эк. ғ. докторы, проф., ҚР ҰҒА академигі Кошанов А.К.; эк.ғ. докторы, проф., ҚР ҰҒА академигі Нәрібаев К.Н. (бас редактордың орынбасары); филос. ғ.докторы, проф., ҚР ҰҒА академигі Нысанбаев А.Н.; заң ғ. докторы, проф., ҚР ҰҒА академигі Сәбікенов С.Н.; заң ғ. докторы, проф., ҚР ҰҒА академигі Сүлейменов М.К.; эк. ғ. докторы, проф., ҚР ҰҒА академигі Сатыбалдин С.С.; тарих ғ. докторы, проф., ҚР ҰҒА академик Әбжанов Х.М.; тарих ғ. докторы, проф., ҚР ҰҒА корр. мүшесі Әбусеитова М.Х.; тарих ғ. докторы, проф., ҚР ҰҒА академик Байтанаев Б.А.; филол. ғ. докторы, проф., ҚР ҰҒА корр. мүшесі Жақып Б.А.; фил. ғ. докторы, проф., академик НАН РК Қалижанов У.К.; филол. ғ. докторы, проф., ҚР ҰҒА академик Қамзабекұлы Д.; тарих ғ. докторы, проф., ҚР ҰҒА академик Қожамжарова Д.П.; тарих ғ. докторы, проф., ҚР ҰҒА академик Койгелдиев М.К.; фил. ғ. докторы, проф., ҚР ҰҒА корр. мүшесі Кұрманбайұлы Ш.; тарих ғ. докторы, проф., ҚР ҰҒА корр. мүшесі Таймағанбетов Ж.К.; социол. ғ. докторы, проф., ҚР ҰҒА корр. мүшесі Шәукенова 3.К.; фил. ғ. докторы, проф., КР ҰҒА корр. мүшесі Дербісәлі А.; саяси. ғ. докторы, проф., Бижанов А.К., тарих ғ. докторы, проф., Кабульдинов 3.Е.; фил. ғ. докторы, проф., ҚР ҰҒА корр мүшесі Қажыбек Е.3.

\section{Р едакция ке н е с i:}

Молдова Республикасының ҰҒА академигі Белостечник Г. (Молдова); Әзірбайжан ҰҒА академигі Велиханлы Н. (Азербайджан); Тәжікстан ҰҒА академигі Назаров Т.Н. (Тәжікстан); Молдова Республикасының ҰҒА академигі Рошка А. (Молдова); Молдова Республикасының ҰҒА академигі Руснак Г. (Молдова); Әзірбайжан ҰҒА корр. мүшесі Мурадов Ш. (Әзірбайжан); Әзірбайжан ҰҒА корр. мүшесі Сафарова 3. (Әзірбайжан); э. ғ. д., проф. Василенко В.Н. (Украина); заң ғ. докт., проф. Устименко В.А. (Украина)

«Қазақстан Республикасы Ұлттық ғылым академиясының Хабарлары. Қоғамдық және гуманитарлық ғылымдар сериясы». ISSN 2224-5294

Меншіктенуші: «Қазақстан Республикасының Ұлттық ғылым академиясы» РҚБ (Алматы қ.)

Қазақстан республикасының Мәдениет пен ақпарат министрлігінің Ақпарат және мұрағат комитетінде 30.04.2010 ж. берілген № 10894-Ж мерзімдік басылым тіркеуіне қойылу туралы куәлік

Мерзімділігі: жылына 6 рет.

Тиражы: 500 дана.

Редакцияның мекенжайы: 050010, Алматы қ., Шевченко көш., 28, 219 бөл., 220, тел.: 272-13-19, 272-13-18, http://nauka-nanrk.kz. social-human.kz

(C) Қазақстан Республикасының Ұлттық ғылым академиясы, 2018

Типографияның мекенжайы: «Аруна» ЖК, Алматы қ., Муратбаева көш., 75. 
Главный редакто $p$

Почетный член НАН РК

T.O. Балыкбаев

Р е дак ци онн а я коллег и я:

докт. экон. Н., проф., академик НАН РК У.Б. Баймуратов; докт. ист. н., проф., академик НАН РК К.М. Байпаков; докт. филос. Н., проф., академик НАН РК Г.Е. Есим; докт. фил. Н., проф., академик НАН РК С.С. Кирабаев; докт. экон. Н., проф., академик НАН РК А.К. Кошанов; докт. экон. Н., проф., академик НАН РК К.Н. Нарибаев (заместитель главного редактора); докт. филос. н., проф., академик НАН РК А.Н. Нысанбаев; докт. юр. Н., проф., академик НАН РК С.Н. Сабикенов; докт. юр. н., проф., академик НАН РК М.К. Сулейменов; докт. экон. Н., проф., академик НАН РК С.С. Сатубалдин; докт. ист. н., проф., академик НАН РК Х.М. Абжанов; докт. ист. н., проф., чл.-корр. НАН РК М.Х. Абусеитова; докт. ист. н., проф., академик НАН РК Б.А. Байтанаев; докт. фил. н., проф., чл.-корр. НАН РК Б.А. Жакып; докт. фиолол. н., проф., академик НАН РК У.К. Калижанов; докт. фил. н., проф., академик НАН РК Д. Камзабекулы; докт. ист. н., проф., академик НАН РК Д.П. Кожамжарова; докт. ист. н., проф., академик НАН РК М.К. Койгельдиев; докт. филол. н., проф., чл.-корр. НАН РК Ш. Курманбайулы; докт. ист. н., проф., чл.корр. НАН РК Ж.К. Таймаганбетов; докт. социол. н., проф., чл.-корр. НАН РК З.К. Шаукенова; д. филол. н., проф., чл.-корр. НАН РК А. Дербисали; доктор политических наук, проф., Бижанов А.К.; доктор ист. наук, проф., Кабульдинов 3.Е.; доктор филол. н., проф., член-корр. НАН РК Қажыбек Е.3.

Р е дак ци онны й с ов е т

академик НАН Республики Молдова Г. Белостечник (Молдова); академик НАН Азербайджанской Республики Н. Велиханлы (Азербайджан); академик НАН Республики Таджикистан Т.Н. Назаров (Таджикистан); академик НАН Республики Молдова А. Рошка (Молдова); академик НАН Республики Молдова Г. Руснак (Молдова); чл.-корр. НАН Азербайджанской Республики Ш. Мурадов (Азербайджан), член-корр. НАН Азербайджанской Республики 3.Сафарова (Азербайджан); д. э. н., проф. В.Н. Василенко (Украина); д.ю.н., проф. В.А. Устименко (Украина)

Известия Национальной академии наук Республики Казахстан. Серия общественных и гуманитарных наук. ISSN 2224-5294

Собственник: РОО «Национальная академия наук Республики Казахстан» (г. Алматы)

Свидетельство о постановке на учет периодического печатного издания в Комитете информации и архивов

Министерства культуры и информации Республики Казахстан № 10894-Ж, выданное 30.04.2010 г.

Периодичность 6 раз в год

Тираж: 500 экземпляров

Адрес редакции: 050010, г. Алматы, ул. Шевченко, 28, ком. 219, 220, тел. 272-13-19, 272-13-18, www:nauka-nanrk.kz / social-human.kz

(C) Национальная академия наук Республики Казахстан, 2018 г.

Адрес типографии: ИП «Аруна», г. Алматы, ул. Муратбаева, 75

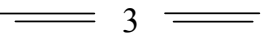


Chief Editor

\section{Honorary member of NAS RK \\ Balykbayev T.O}

Editorial board:

Doctor of economics, prof, academician of NAS RK Baimuratov U.B.; doctor of history, prof, academician of NAS RK Baipakov K.M.; doctor of philosophy, prof, academician of NAS RK Esim G.E.; doctor of philology, prof, academician of NAS RK Kirabayev S.S.; doctor of economics, prof, academician of NAS RK Koshanov A.K.; doctor of economics, prof, academician of NAS RK Naribayev K.N. (deputy editor-in-chief); doctor of philosophy, prof, academician of NAS RK Nyssanbayev A.N.; doctor of law, prof, academician of NAS RK Sabikenov S.N.; doctor of law, prof, academician of NAS RK Suleymenov M.K.; doctor of economy, prof, academician of NAS RK Satybaldin S.S.; doctor of history, prof, academician of NAS RK Abzhanov H.M; doctor of history, prof, corresponding member of NAS RK Abuseitova M.H.; doctor of history, prof, academician of NAS RK Baitanaev B.A.; doctor of philology, prof, corresponding member of NAS RK Zhakyp B.A.; doctor of philology, prof, academician of NAS RK Kalizhanov U.K.; doctor of philology, prof, academician of NAS RK Hamzabekuly D.; doctor of history, prof, academician of NAS RK Kozhamzharova D.P.; doctor of history, prof, academician of NAS RK Koigeldiev M.K.; doctor of philology, prof, corresponding member of NAS RK Kurmanbaiuly Sh.; doctor of history, prof, academician of NAS RK Taimaganbetov J.K.; doctor of sociology, prof, corresponding member of NAS RK Shaukenova Z.K.; doctor of philology, prof, corresponding member of NAS RK Derbisali A.; doctor of political science, prof Bizhanov A.K; doctor of History, prof Kabuldinov Z.E.; doctor of philology, prof, corresponding member of NAS RK Kazhybek E.Z.

\section{Editorial staff:}

Academician NAS Republic of Moldova Belostechnik.G (Moldova); Academician NAS Republic of Azerbaijan Velikhanli N. (Azerbaijan); Academician NAS Republic of Tajikistan Nazarov T.N. (Tajikistan); Academician NAS Republic of Moldova Roshka A. (Moldova) Academician NAS Republic of Moldova Rusnak G. (Moldova); Corresponding member of the NAS Republic of Azerbaijan Muradov Sh. (Azerbaijan); Corresponding member of the NAS Republic of Azerbaijan Safarova Z. (Azerbaijan); Associate professor of Economics Vasilenko V.N. (Ukraine), Associate professor of Law Ustimenko V.A. (Ukraine)

News of the National Academy of Sciences of the Republic of Kazakhstan. Series of Social and Humanities. ISSN 2224-5294

Owner: RPA "National Academy of Sciences of the Republic of Kazakhstan" (Almaty)

The certificate of registration of a periodic printed publication in the Committee of information and archives of the Ministry of culture and information of the Republic of Kazakhstan N 10894-Ж, issued 30.04.2010

Periodicity: 6 times a year

Circulation: 500 copies

Editorial address: 28, Shevchenko str., of. 219, 220, Almaty, 050010, tel. 272-13-19, 272-13-18, www:nauka-nanrk.kz / social-human.kz

(C) National Academy of Sciences of the Republic of Kazakhstan, 2018

Address of printing house: ST "Aruna", 75, Muratbayev str, Almaty 
N E W S

OF THE NATIONAL ACADEMY OF SCIENCES OF THE REPUBLIC OF KAZAKHSTAN

SERIES OF SOCIAL AND HUMAN SCIENCES

ISSN 2224-5294

https://doi.org/10.32014/2018. 2224-5294.19

Volume 5, Number 321 (2018), 106 - 112

\author{
A. Karatayeva, Zh. Berdiarova \\ Candidate of Jurisprudence, Associate Professor of Department of the Theory and History of State and Law, \\ Constitutional and Administrative Law, Law Faculty, Al-Faraby KazNU; \\ Candidate of Jurisprudence, Associate Professor of Department of the Civil and Ecological Law, L.N. Gumilyov \\ Eurasian National University
}

\title{
THE ETHICAL CULTURE AND LEGAL CULTURE CIVIL SERVANTS AS TO BASIS OF ANTICORRUPTION CULTURE
}

\begin{abstract}
The paper considers the substantive part of the anticorruption legal culture. Also in the paper comprehensively researched and the relation to the legal culture and legal education. The paper also focuses on the formation and development of such phenomena as culture and civilization. The main conclusions and points the author may be used in the formation and development of legal culture, to increase the legal awareness and legal education of Kazakh society.
\end{abstract} State.

Keywords: legal culture, legalcivilization, legal education, the state, the public authority, the activities of the

Kazakhstan and international experience of combating corruption shows that the use of some legal measures is not enough to successfully combat this negative.

At the present stage of the development of the rule of law and civil society, the improvement of the public service institution and the enhancement of the ethical and legal culture of the civil servant is an important and urgent problem.

Transformations taking place in the system of public service of the Republic of Kazakhstan can be developed only in conditions of comprehensive and effective legislative support and increasing the legal awareness and legal culture of a civil servant.

Observance of culture, ethics, morality and moral values should always be manifested, not only in the state structure, but also in society.

Culture as a whole is the totality of the spiritual and material achievements of society. It represents the social and progressive creative activity of an individual in various spheres of being and consciousness, is the unity of the processes of creating values, norms for the development of cultural heritage.

As Professor Ibraeva A.S. "Legal culture, as well as any other kind of culture, is subject to estimates. Hence it seems possible to talk about the role of law in the formation of a high culture with an orientation toward an average level and overcoming a low level. Of course, the estimates will be relative. Different people, different communities of people, political parties, persons in power, and the opposition can assess cultural achievements in the state and legal sphere. Both from the subjective and the objective side, there are serious obstacles in achieving unity of interpretation of legal phenomena as cultural gains. Nevertheless, these obstacles are surmountable. History has already developed some generalized criteria for determining the level of culture, and on this basis, an opportunity is created to determine the main directions for raising the legal culture, including through the law. These include: the formation of a sense of law and the rule of law; mastering the achievements of logical and legal thinking; improvement of legislation; increasing the volume and qualitative improvement of law-abiding behavior; improvement of jurisdictional and other law enforcement activities; separation of powers of legislative, executive and judicial institutions; study of monuments of law and law enforcement practice as the basis of legal education "[1, p. 158].

In accordance with Article 1 of the Law "On Public Service of the Republic of Kazakhstan" of November 23, 2015, "A civil servant is a citizen of the Republic of Kazakhstan who, in accordance with

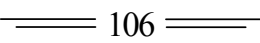


the procedure established by the legislation of the Republic of Kazakhstan, is paid by the state or public office from the republican or local budgets or from the National Bank of the Republic of Kazakhstan body and exercising official powers with a view to realizing the tasks and functions of the state [2].

In turn, civil servants are divided into:

1) an administrative civil servant is a civil servant who carries out his activity on a permanent professional basis, except for cases provided for by laws of the Republic of Kazakhstan and acts of the President of the Republic of Kazakhstan;

2) political civil servant - civil servant, appointment (election), the release and activity of which are politically-determining, which is responsible for the implementation of political goals and objectives [2].

Based on the law, you can identify signs that are common to all civil servants:

1) possession of citizenship of the Republic of Kazakhstan;

2) achievement of at least 18 years of age;

3) possession of full legal capacity;

4) the state of health is quite satisfactory for the performance of official duties;

5) law-abiding (absence of outstanding criminal record, failure to take disciplinary responsibility for committing a corruption offense or administrative responsibility for an intentional offense within one year before entering the civil service);

6) availability of necessary vocational education;

7) holding a position in a state body,

8) receiving a monetary reward for their activities from

funds of the republican or local budget or from the National Bank;

9) implementation of activities in strict compliance and within the limits established by law, its focus on the implementation of the tasks and functions of the state;

10) imposing on the civil servant certain restrictions and mandatory requirements;

11) fixing of special measures in the legislation on material

maintenance of activity of civil servants, their social protection, encouragement;

12) responsibility for their activities [3, p. 56].

Ethical and legal culture of a civil servant creates a legal culture of the state and society as a whole.

The effectiveness of the public service system largely depends on the rules of conduct of a civil servant in the service. Here it should be emphasized especially that the system of norms of conduct and the rules of mutual relations in the public service are norms of universal morality. This is the essence of the ethic of the civil servant. By professional ethics is understood a set of rules of conduct, in other words, the moral code of people, of any profession.

The ethical culture and legal culture of a civil servant is related to the fact that its activities must meet not only the norms of existing legislation, but must also comply with the principles and norms of morality.

In this regard, it should be noted that the Ethical Code of the civil servant is not only based on morality, but also relies on its requirements.

The level of professional legal culture and professional consciousness of a civil servant is determined by the quality of their activities and work.

Any reforms to improve the civil service system will be useless if the level of ethical and legal culture of a civil servant is low.

According to Ibraeva A.S. "Professional consciousness is understood as an element of professional culture, and the basis of its content is professional, legal and professional-moral consciousness functioning in unity and interaction with the political, aesthetic and other spheres of social consciousness" [1, p. 166].

One of the important legal acts regulating relations in the state service is the consolidation of the rule of official ethics of state employees. This provision is reflected in the Ethical Code of Civil Servants of the Republic of Kazakhstan, approved by the Decree of the President of the Republic of December 29, 2015. for No. 153. The Code is aimed at strengthening public confidence in state bodies, forming a high culture of relations in the civil service and preventing cases of unethical behavior of civil servants [4].

This legal act determined mandatory for compliance with all government officials the basic standards of their behavior and enshrined anti-corruption provisions and norms.

The Code of Ethics defines general standards for the behavior of civil servants, standards of conduct during off-duty hours, behavior in official relations, and public statements, including in the media. 
A number of norms in the Code of Ethics are of a moral and ethical nature. Compliance with the norms of the Code is the official duty of every state employee.

The civil servant should be a model of morality, culture and justice for all, with whom he has to interact. First of all, he must be law-abiding, committed, responsible. A civil servant should always have a management culture.

State employees in service relations with colleagues should:

1) to promote the establishment and strengthening in the team of business and benevolent relationships and constructive cooperation;

2) to prevent or take other measures to prevent violations of standards of professional ethics from other public servants;

3) refrain from discussing the personal and professional qualities of colleagues defaming their honor and dignity in the team;

4) not allow actions (inaction) that impede the performance by colleagues of their official duties [4].

Public opinion about civil servants is largely their behavior during off-duty hours. In the Ethics Code, the norms of official ethics of civil servants were reflected in off-duty time.

Government employees during off-duty time should:

1) adhere to the generally accepted moral and ethical norms, not to allow cases of antisocial behavior, including being in public places in a state of intoxication, which offends human dignity and public morality;

2) to show modesty, not to emphasize and not use his official position when receiving the relevant services;

3) not to allow on its part violations of the requirements of legislation, involving an infringement of public morality, order and security, and not involve other citizens in committing unlawful, antisocial actions [4].

The state service acts as a mechanism for consolidating spiritual values and creating a cultural atmosphere. Spiritual values consist of cultural norms that are formed in the process of development of the institution of public service.

According to the Ethical Code of civil servants of the Republic of Kazakhstan, civil servants must:

1) to contribute to strengthening the unity of the people of Kazakhstan and interethnic harmony in the country, to respectfully respect the state and other languages, traditions and customs of the people of Kazakhstan;

2) to be honest, fair, modest, respect the generally accepted moral and ethical standards, and treat citizens and colleagues with courtesy and correctness;

3 ) ensure the legality and fairness of the decisions they make;

4) ensure transparency in the adoption of decisions affecting the rights and legitimate interests of individuals and legal entities;

5) to resist actions that damage the interests of the state, hamper or reduce the effectiveness of public authorities;

6) raise their professional level and qualifications for effective performance of official duties, comply with the restrictions and prohibitions established by the laws of the Republic of Kazakhstan;

7) by their actions and behavior, not to give rise to criticism from the public, not to be persecuted for criticism, to use constructive criticism to eliminate shortcomings and improve their activities;

8) not use the official position to influence the activities of state bodies, organizations, civil servants and other persons when solving personal issues;

9) not disseminate information that does not correspond to reality;

10) to ensure the preservation of state property, rationally, effectively and only for official purposes to use the entrusted state property, including motor vehicles;

11) strictly observe the official discipline, conscientiously, impartially and qualitatively fulfill their official duties, rationally and effectively use working time;

12) on an ongoing basis take measures to improve the quality of public services provided, fully focusing on the needs of the public as a consumer of public services;

13) not allow the commission of misdemeanors and other offenses for which disciplinary, administrative or criminal liability is provided by law. 
14) observe business etiquette and rules of official conduct [4].

Of all legal mechanisms, the Ethical Code of Civil Servants is effective, which affects the justice and morality of the civil servant.

The development and implementation of the Ethical Code of Civil Servants of the Republic of Kazakhstan is one of the directions for the implementation of the state policy in the sphere of combating corruption and enhancing the anti-corruption legal culture of civil servants.

Corruption is an offense socially harmful, contrary to the requirements of legal norms.

As Turisbek A.Z. "Society and each citizen individually is not indifferent to what means and by what rules the goals set for the state service are achieved. Therefore, the issue of the ethics of relations, both within each state body, and between state bodies and society, is becoming increasingly acute. This is very important for the state and society as a whole, since they are interested in ensuring that professionals with high moral qualities work in the public service "[3, p. 57].

The main task of the Ethical Code of civil servants should be the prevention and prevention of corruption offenses. The adoption of the Code of Ethics for civil servants of the Republic of Kazakhstan is a significant step in countering corruption.

In this regard, in our opinion, every civil servant should:

- The civil servant must always be loyal to the state, do not put his interests above the state;

- a civil servant must always perform his duties conscientiously;

- The civil servant should not use his official powers for his own benefit;

- a civil servant should not use confidential information for his own benefit;

- The civil servant is obliged to prevent any corrupt acts, to show intolerance towards them.

Anticorruption education of society should be an integral part of moral education, the formation of an anti-corruption culture.

Anticorruption culture embraces the quality of the individual, including knowledge of the dangers of corruption for the welfare of the state and the security of society.

Anticorruption culture is a person's condition, which seeks to eliminate corruption offenses.

Anticorruption culture is a value setting aimed at showing an active civic position regarding corruption.

In this regard, we can identify the signs of behavior according to the degree of anti-corruption consciousness:

- the ability to recognize corruption as a dangerous social phenomenon;

- the ability to assess the harm of corruption;

- use all means to reduce corruption;

- to contribute to the prevention of corruption;

- to be able to interpret the rules of law;

- apply theoretical legal knowledge in practice;

- Know the rules of law and apply them to protect their rights.

The level of legitimacy of an individual's actions reflects the anti-corruption culture of a person.

Law-abiding, legal activity, morality, responsibility to society and the state - there is an anticorruption culture.

In this regard, we can distinguish the following functions of the anti-corruption culture:

1. Cognitive function, which is characterized by individual comprehension of corruption phenomena in legal practice. In the process of implementing this function, the anti-corruption processes taking place in various social systems (for example: educational, political and economic systems) are studied and explained. Cognitive function is not limited only to the definition or explanation of cause-effect relationships of various anti-corruption phenomena, which does not bring us nearer to the knowledge of anti-corruption culture. It is aimed at revealing the deep processes, which are based on the problems that are the essence, the root cause of the emergence of corruption;

2. The modeling function serves as a means of forming an appropriate model of anti-corruption behavior. In the process of implementing this function, there is a certain image or standard of the person's anti-corruption behavior that corresponds to legal norms; 
3. The regulatory function makes it possible to compare its anti-corruption behavior with legal requirements [5].

Anticorruption culture of civil servants can have a serious impact on the development of the public service system, contribute to strengthening the rule of law and order in society, create conditions for the effective functioning of the state and legal system.

Thus, the anti-corruption culture of a civil servant reflects his patriotism to his homeland, civic activity, conscientiously fulfilling his official duties.

The basis of anti-corruption culture is the legal culture of every civil servant, which leads to strengthening of the rule of law, strict observance of the rule of law.

To ensure and effective functioning of anti-corruption activities:

- civil servants are not obliged to give preference to anyone in the performance of civil service;

- a civil servant, when performing official official duties, should not allow personal interest, which may lead to conflicts of interest;

- civil servants are obliged to provide information on income in accordance with the legislation of the Republic of Kazakhstan;

- Civil servants are obliged to notify of corruption offenses.

According to the Ethical Code of civil servants of the Republic of Kazakhstan, civil servants should not use their official position and related opportunities in the interests of public and religious associations, other non-profit organizations, including for propaganda of their attitude towards them. Civil servants, including those in senior positions, can not openly demonstrate their religious beliefs in the team, force subordinate employees to participate in the activities of public and religious associations, other non-profit organizations [4].

In order to increase the anti-corruption culture of civil servants, in our opinion, it is necessary:

- constantly raise anti-corruption education;

- raise the level of anti-corruption literacy and anti-corruption culture;

- conduct anti-corruption propaganda;

- conduct public information activities on anti-corruption issues;

- constantly interact with civil society in the fight against corruption.

For example, the Singapore Anti-Corruption Strategy of 1965 was based on three basic principles: meritocracy, pragmatism and honesty.

The effectiveness of anti-corruption policies directly depends on personnel policy.

Personnel processes in the public service system are reflected in the quality of life of society.

As A. Makulbekova points out, "it is necessary to agree with the need for a radical revision of the process of training and training future managers. The modern leader needs to possess not only professional, but also strategic, social, functional competence. A modern manager should not so much command, as skillfully lead and inspire workers, that is, be a real leader. Increase in service should be accompanied by a constant increase in education and knowledge "[6, p. 43].

Berdaliev K.B. identifies three main criteria, the process of training and training of civil servants:

First, the correspondence of the individual characteristics of the candidate to the profile of the ideal employee for this position - the manager;

Secondly, the results of work on previously held posts;

Thirdly, it is necessary to take into account the candidate's degree of willingness to "age-potential" parameters and take into account the evaluation of his efforts to prepare for this position [7, p. eleven].

The effectiveness of personnel work depends, first, on the moral and moral foundations of the civil service; second, from the legal regulation of professional ethics of representatives of power structures; thirdly, from the use of mechanisms of direct social influence on the formation of the proper morale of civil servants [8]. According to Makulbekova A. "Kazakhstan model allowed to consolidate institutional measures that contribute to the professionalization of the activities of government. A system of training has been created and is being implemented aimed at implementing a continuous process of increasing the level of knowledge, skills and skills of officials, their further career growth, that is, a new corps of politicians is being formed, and specialists of a broader profile who have received education in prestigious 
higher education institutions of the republic and abroad come to the civil service. In general, it can be said with confidence that in the field of personnel management of the civil service, not a small amount of experience has been accumulated. But at the same time, there are a number of problems that reduce the effectiveness of civil servants and do not allow the proper use of the existing human resources to the extent possible. In our opinion, the lack of clearly defined strategic goals, the lack of a scientific justification and a systematic approach to solving personnel problems, taking into account the social and psychological state of civil servants, the low level of resource support for the human resources management system, including information and scientific and methodological use of administrative resources, still there are obsolete methods and technologies of personnel management, low authority of officials, mainly because of corruption in state bodies the control. All this gives grounds to say that at present the work with the staff of the state apparatus requires a certain administrative mechanism, the use of the system scientific approach of employees [6, p. 46].

The development of society and the globalization of the states of the world lead to constant reforms of the state apparatus, the development of new approaches and methods of state administration. All this should be done consistently, the main goal of which should be to reform the functions of the state and the civil service.

The civil servant must possess moral qualities, have ethical knowledge, moral sense, will for practical implementation.

The main factors that reduce the authority of civil servants are such components as low educational level; low level of culture of communication with citizens; low level of professionalism; strongly bureaucratic control apparatus, "stimulating" its employees for immoral actions; high level of corruption among government officials; ubiquitous use of official powers for mercenary purposes, etc. And in order to increase the confidence of state bodies in society, in our opinion, the state should create maximum conditions for the formation of spiritual and moral values in society. Therefore, the basis of the true authority of a civil servant who upholds the authority of the state must be, above all, his competence in the exercise of his official powers and the observance of ethical conduct. One of the basic principles that should be the basis of public service should be the principle of the commitment of the civil servant to the interests of the civil service, devotion to the business with which he is engaged. Devotion is seen as a moral quality. In addition, she has a direct relationship to the professional qualities of a civil servant [9].

Thus, raising the ethical culture and legal culture of civil servants should be one of the priorities of state policy and anti-corruption strategies. It should include legal literacy, legal education, legal education, moral qualities and principles of ethics and morality.

\section{REFERENCES}

[1] Ibrayeva A.S. Legal culture: problems of theory and practice. Almaty, 2002. $352 \mathrm{s.}$

[2] Law "On Public Service of the Republic of Kazakhstan" of November 23, 2015 // http://adilet.zan.kz.

[3] Turisbek A.Z. Legal mechanisms for the formation of the corps of administrative civil servants in the Republic of Kazakhstan. - Thesis for the degree of Doctor of Law. Almaty, 2005. 160 p.

[4] Ethical Code of Civil Servants of the Republic of Kazakhstan / Decree of the President of the Republic of Kazakhstan dated December 29, 2015. № 153 // https://online.zakon.kz.

[5] Ibragimova EM, Hamdeev AR The essence of the concept of anti-corruption culture and its functions / Modern problems of science and education. 2013. № 3 // https://www.science-education.ru

[6] MakulbekovaAybupe Legal principles of development of public service system of the Republic of Kazakhstan. - Thesis for the degree of Doctor of Law. Almaty, 2009. $142 \mathrm{p}$.

[7] Bertaliev K.B. Basics of managing the economy of Kazakhstan. - Almaty: Economics, 1998. P. 247.

[8] Safonov O.I. Ethical bases of counteraction of corruption of the civil servant / the Electronic bulletin of the Rostov social and economic institute.Issue number 3-4. 2015. P.931-941// https://cyberleninka.ru

[9] Makulbekova A. Spiritual and moral education of civil servants // https://articlekz.com/article/10023 


\section{А.М. Каратаева, Ж.С. Бердиярова}

заң ғылымдарының кандидаты, Әл-Фараби атындағы ҚазҰУ-дің заң факультеті, мемлекет және құқық теориясы мен тарихы, конституциялық және әкімшілік құқығы кафедрасының доценті;

заң ғылымдарының кандидаты, Л.Н. Гумилев атындағы Еуразиялық ұлттық университеті, азаматтық және экологиялық құқық кафедрасының доценті

\section{МЕМЛЕКЕТТІК ҚЫЗМЕТШІНІН ӘДЕПТІК МӘДЕНИЕТІ ЖӘНЕ ҚҰҚЫҚТЫҚ МӘДЕНИЕТІ СЫБАЙЛАС ЖЕМҚОРЛЫҚҚА ҚАРСЫ МӘДЕНИЕТТІҢ НЕГІЗІ РЕТІНДЕ}

Аннотация. Жұмыста сыбайлас жемқорлыққа қарсы құқықтық мәдениеттің мазмұндық тұстары ашылып, қарастырылады. Сонымен қатар, құқықтық мәдениеттің және құқықтық тәрбиенің арақатынастары және ерекшеліктері талданып, жан жақты зерттелінеді.

Сондай ақ мақаланың авторы мәдениет пен өркениеттің қалыптасуы мен дамуына аса назар бөледі. Автордың қол жеткізген нәтижелері мен қорытындыларын қазақстандық құқықтық мәдениеттің қалыптасуы мен дамуына, қоғамның құқықтық санасын арттыруға, қоғамның құқықтық тәрбиесін көтермелеуге ісінде қолдануға болады.

Түйін сөздер: құқықтық мәдениет, құқықтық өркениет, құқықтық тәрбие, мемлекет, мемлекеттік орган, мемлекеттің қызметі

\section{А.М.Каратаева, Ж.С.Бердиярова}

кандидат юридических наук, доцент кафедры гражданского и экологического права Евразийского национального университета, имени Л.Н. Гумилева;

кандидат юридических наук, доцент кафедры теории и истории государства и права, конституционного и административного права юридического факультета КазНУ имени аль-Фараби

\section{ЭТИЧЕСКАЯ КУЛЬТУРА И ПРАВОВАЯ КУЛЬТУРА ГОСУДАРСТВЕННЫХ СЛУЖАЩИХ КАК ОСНОВА АНТИКОРРУПЦИОННОЙ КУЛЬТУРЫ}

Аннотация. В работе рассматриваются содержательные стороны антикоррупционной правовой культуры. Также в работе всесторонне исследуются соотношение и особенности правовой культуры и правового воспитания.

В работе также особое внимание уделяется на формирование и развитие таких феноменов как культура и цивилизация. Основные выводы и положения автора могут быть использованы в формировании и развитии правовой культуры, в повышении правосознания и правового воспитания казахстанского общества.

Ключевые слова: правовая культура, правовая цивилизация, правовое воспитание, государство, государственный орган, деятельность государства.

Information about author:

Karatayeva A. - Candidate of Jurisprudence, Associate Professor of Department of the Theory and History of State and Law, Constitutional and Administrative Law, Law Faculty, Al-Faraby KazNU; https://orcid.org/0000-0003-3471-1583;

Berdiarova Zh. - Candidate of Jurisprudence, Associate Professor of Department of the Civil and Ecological Law, L.N. Gumilyov Eurasian National University, https://orcid.org/0000-0002-4949-9522 


\section{МАЗМҰНЫ}

Алтыбаева С.М., Савындыков Е.С. Көркем мәтін құрылымындағы мифопоэтикалық модельдеу және мәдени код...... 5 Сембиева Л.М., Мажитов Д.М., Карпиикая М.Е., Хамитова Д.М. Экономиканы жаңғырту жағдайындағы ЕАЭО елдерінің монетарлық жүесінін өзгеруі .....

Құлсариева А.Т., Султанова М.Э., Шайгозова Ж.Н. Фольклор және сәйкестілік: Қазақстанның қазіргі заманғы

мәдениетіндегі тарих, жады және аңыз шығармашылығы ........................................................................................... 19

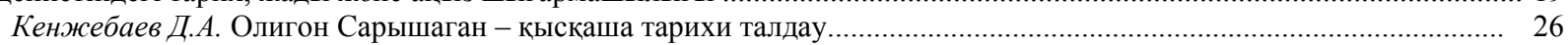

АбдулинаГ.А., БазарбаевА.Г. Ұйымдардағы адам ресурстарын басқарудың заманауи тұжырымдамалары................ 33

Авыбаев А.Н., Адибаева А.К. Геноцид туралы БҰҰ Конвенциясының қатысушы мемлекеттердің қылмыстық

заңнамаларындағы имплементациялық тетіктері: жалпы салыстырмалы талдау............................................................ 39

Ахметжанов Б., Тәжібекова К.Б., Шаметова А.А. Қазақстан көлік өнеркәсіптің дамуын талдау............................. 44

Аюпова 3.К., Құсайынов Д.Ө. Тәуелсіздік жағдайындағы қазақстан республикасының конституциялық-құқықтық

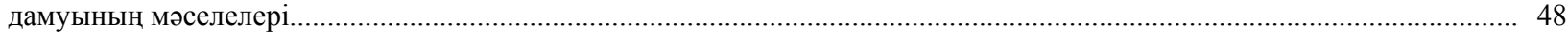

Нурпеисова А.А., Рей И.Ю., Бижанов Д.Т., Тлеужанова Д.А. Инновациялық өндірісді жасаудың процесін

бақылауының негізгі элементтері

Гиздатов Г.Г. Қазақстандық дискурсының құрылымы психолингвистиякалық зерттеу .

Ищанова Р.К. Мемлекеттік шығындарды басқару - мемлекеттің қаржылық тұрақтылығын қамтамасыз ету.............. 64

Мадышева А.М. Бикенова А.С., Елеусиз Л.Т. Білім саласындағы туристік қызметтер............................................. 68

Ескалиева А. Ж., Баймуханова М.Т., Ахмурзина Д.О. Әлеуметтік сала адам капиталының сапасын қолдаудың

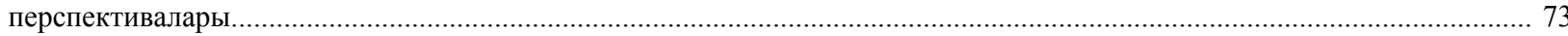

Мархаева Б.А., Козбахова Д.Л. Жауапкершілік орталық және трансферттік баға белгілеу............................................ 79

Сабирова Р.К., Утепкалиева К.М., Кабаков С.Б. Қазақстандағы ауыл шаруашылығы экономикасының

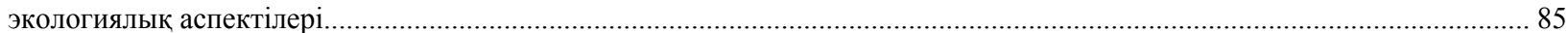

Тлесова Э., Хойч А., Кураш Н. Қазақстан республикасының ғылыми инновациялық потенциясы және оның

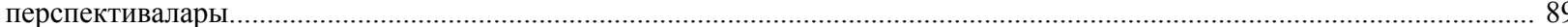

Хамитхан Н. Қазақстандағы банктік қызметтердің сапасын жақсарту жағдайында банкаралык басекелестік............ 95

Шалдарбеков Қ.Б., Муханова Г.С., Нурмухамбетова 3.С. Аймақтарды дамыту бағдарламаларын жүзеге асырудағы жобалық басқаруды қолданудың шетелдік тәжірибесі

КаратаеваА.М., Бердиярова Ж.С. Мемлекеттік қызметшінің әдептік мәдениеті және құқықтық мәдениеті

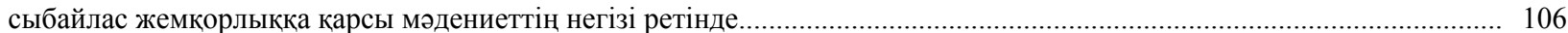

Алдабергенова А.А. Абсурд әдебиетін аударудың лингвомәдени аспектілері ................................................... 113

Стукач В. Ф., Байдалинова А. С., Сандыбаева Б. А. Қазақстанның қаржылық қауіпсіздігі......................................... 119

Баймаханова Д.М., Оспанова Д.А. Конституциялық-құқықтық сана - конституционализмнің маңызды

компоненті ретінде және оның адам құқықтары мәселелерін шешудегі рөлі................................................................. 126

Имангожина 3.А. Сланцевая революция: глобальный тренд на мировом энергетическом рынке............................. 137

Ракаева А.Н., Жуматаева Б.А., Успамбаева М.К., Доскалиева Б.Б. Экологиялық есеп қазақстандағы кәсіпорын экономикасының даму кезеңі ретінде

Нуржанова Г.И. Экономиканың аграрлық секторындағы еңбек әлеуетіне демографиялық фактордың әсері............ 147

Оспанова Д.А., Баймаханова Д.М. Қазақстан Республикасының кибер кеңістігін дамыту жағдайында мемлекеттік қызметтерді цифрландыруда әкімшілік-құқықтық қамтамасыз ету ................................................................................... 152

Pblсnекова М.О., Тлесова Э.Б., Хаитбаева Ф.К. Қазақстандағы тұрғын үй-коммуналдық шаруашылық қызметін

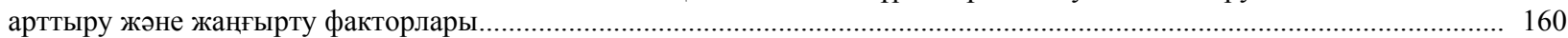

Султанова Г. Т. Аграрлық сектордың экспорттық әлеуетін дамытуға бағытталған үрдістер мен басымдықтар........ 166 


\section{СОДЕРЖАНИЕ}

Алтыбаева С.М., Сагындыков Е.С. Культурный код и мифопоэтическое моделирование в структуре художественного текста.

Сембиева Л.М., Мажитов Д.М., Карпиикая М.Е., Хамитова Д.М. Трансформация монетарной системы стран

ЕАЭС в условиях модернизации экономики.............................................................................................................

Кулсариева А.T., Султанова М.Э., Шайгозова Ж.Н. Фольклор и идентичность: история, память и мифотворчество

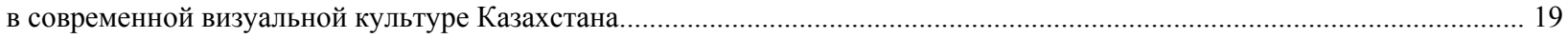

Кенжебаев Д.А. Полигон Сарышаган - краткий исторический анализ................................................................ 26

Абдулина Г.А., БазарбаевА.Г. Современные концепции управления человеческми ресурсами в организациях........... 33

Агыбаев А.Н., Адибаева А.К. Имплементационные механизмы Конвенции ООН о геноциде в уголовных

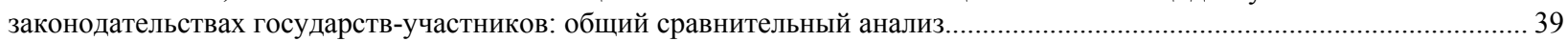

Ахметжанов Б., Тажибекова К.Б., Шаметова А.А. Анализ развития угольной промышленности Казахстана........... 44

Аюпова 3.К., Кусаинов Д.У.Проблемы конституционно-правового развития республики Казахстан в условиях

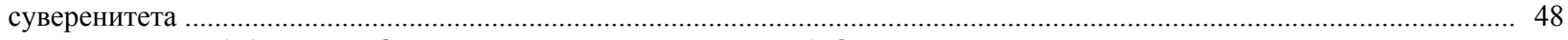

Нурпеисова А.А., Рей И.Ю., Бижанов Д.Т., Тлеужанова Д.А. Основные элементы управления процессом создания

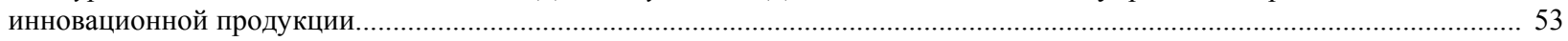

Гиздатов Г.Г. Психолингвистическое исследование концептов казахстанского дискурса...................................... 57

Ищанова Р.К. Управление государственными расходами - как обеспечение финансовой устойчивости государства. 64

Мадымева А.М. Бикенова А.С., Елеусиз Л.Т. Туристские услуги в сфере образования........................................... 68

Ескалиева А. Ж., Баймуханова М.Т., Ахмурзина Д.О. Перспективы усиления качества человеческого капитала

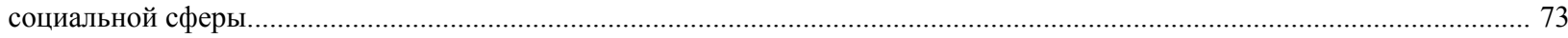

Мархаева Б.А., Козбахова Д.Л. Центр ответственности и трансфертное ценообразование..................................... 79

Сабирова Р.К., Утепкалиева К.М., Кабаков С.Б. Экологические аспекты экономики сельского хозяйства

в Казахстане........................................... 85

Тлесова Э., Хойч А., Кураш Н. Научно-инновационный потенциал республики Казкастан и его перспективы............ 89

Хамитхан Н. Межбанковская конкуренция в условиях повышения качества банковских услуг в Казахстане.............. 95

Шалдарбеков К.Б., Муханова Г.С., Нурмухамбетова 3.С. Зарубежный опыт применения проектного управления

при реализации программ развития регионов

Каратаева А.М., Бердиярова Ж.С. Этическая культура и правовая культура государственных служащих

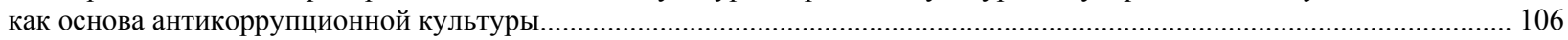

Алдабергенова А.А. Лингвокультурологические аспекты перевода литературы абсурда.......................................... 113

Стукач В. Ф., Байдалинова А. С., Сандыбаева Б. А. Казахстанская финансовая безопасность.................................... 119

Баймаханова Д.М., Оспанова Д.А. Конституционно-правовое сознание как важный компонент конституционализма

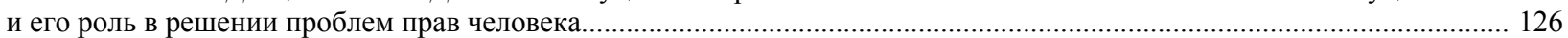

Имангожина 3.A. Сланцевая революция: глобальный тренд на мировом энергетическом рынке............................. 137

Ракаева А.Н., Жуматаева Б.А., Успамбаева М.К., Доскалиева Б.Б. Экологический учет как ступень развития

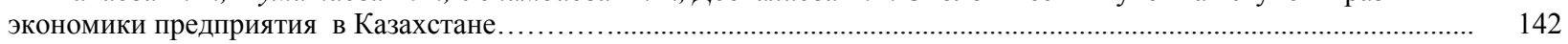

Нуржанова Г.И. Влияние демографического фактора на трудовой потенциал аграрного сектора экономики............ 147

Оспанова Д.А., Баймаханова Д.М. Административно-правовое обеспечение цифровизации государственных услуг

в условиях развития кибер пронстранства республики Казахстан..

Pыспекова М.О., Тлесова Э.Б., Хаитбаева Ф.К. Факторы инновационной модернизации и совершенствования

деятельности жилищно-коммунального хозяйства в Казахстане.

160

Султанова Г. Т. Тенденции и приоритеты развития экспортного потенциала аграрного сектора................................ 166 


\section{CONTENTS}

Altybayeva S.M., Sagyndykov E.S. Cultural code and myth poetic modeling in the structure of the artistic text..................... 5 Sembiyeva L.M., Mazhitov D.M., Karpitskaya M.E., Khamitova D.M. Transformation of the monetary system of the eurasian economic UNION countries in the conditions of modernization of the economy......

Kulsarieva A.T., Sultanova M.E., Shaigozova Zh.N. Folklore and identity: history, memory and myth-making in the modern

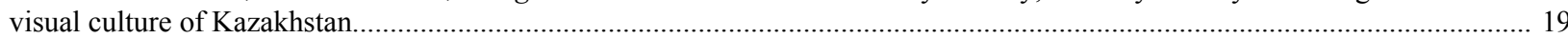

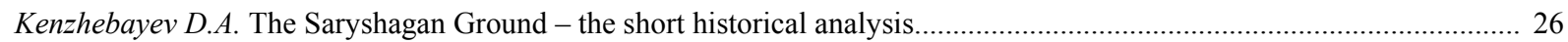

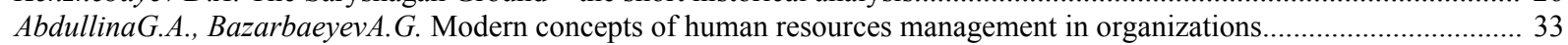

Agybayev A.N., Adibayeva A.K. Implementing mechanisms of the UN Convention on genocide in the criminal legislation

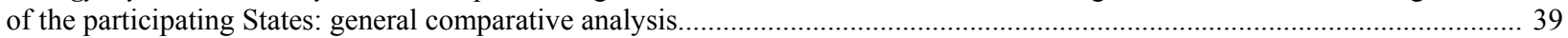

Akhmetzhanov B., Tazhibekova K.B, Shametova A.A. Analysis of development of the coal industry of Kazakhstan.............. 44 Ayupova Z.K., Kussainov D.U. Problems of constitutional and legal development of the republic of kazakhstan in the conditions of sovereignty......

Nurpeisova A.A., Rey I.Yu., Bizhanov D.T., Tleuzhanova D.A. Main elements of managing the process of creating innovation production.

Gizdatov G.G. Psycholinguistic study of the concepts of Kazakhstar

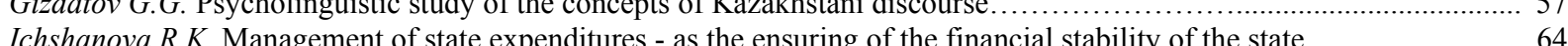

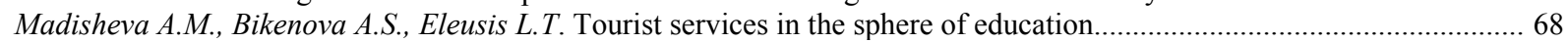

Eskalieva A. Zh., Baymukhanova M.T., Ahmurzina D.O. Perspectives of strengthening the quality of the human capital

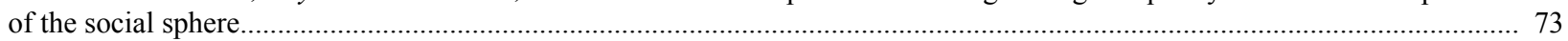

Markhayeva B.A., Kozbakhova D.L. A responsibility center and transfer pricing ................................................. 79

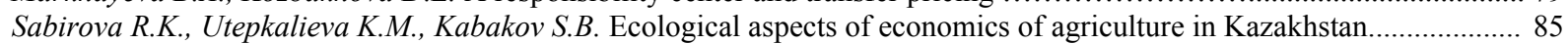

Tlessova E., Khoich A., Kurash N. Scientific innovation potential of the republic of Kazkahstan and its perspectives........ 89

Hamitkhan $N$. Interbank competition in conditions of improving the quality of banking services in Kazakhstan.................. 95

Shaldarbekov K., Mukhanova G., Nurmukhambetova Z. International practices in project management in implementing

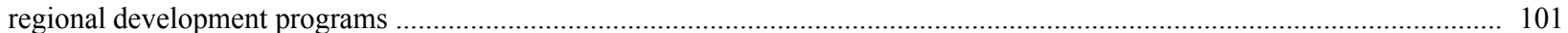

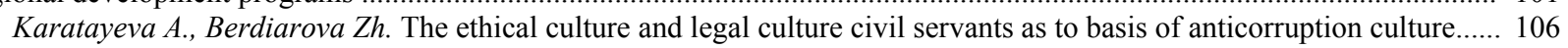

Aldabergenova A.A. Linguocultural aspects of translation of absurd literature.............................................................. 113

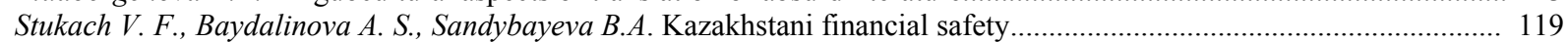

Baimakhanova D.M., Ospanova D.A. Constitutional and legal consciousness as an important component of constitutionalism

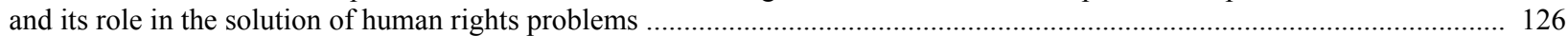

Imangozhina Z.A. Shale gas revolution: global trend in the world energy market..................................................... 137

Rakaeva A.N., Zhumataeva B.A., Uspanbayeva M.K., B.B.Doskalieva. Level of ecological report development in the economic of Kazakhstan's companies.

Nurzhanova G.I. Impact of demographic factors on labor potential of economy's agricultural sector

Ospanova D.A., Baimakhanova D.M. Administrative and legal support of digitalization of public services in the context of the development of cyber space in the republic of Kazakhstan....

Ryspekova M.O., Tlessova E.B., Khaitbayeva F. Factors of innovative modernization and improvement of activity

of housing and communal services in Kazakhstan.

Sultanova G. T. Trends and priorities for the development of export potential of the agrarian sector. 


\title{
PUBLICATION ETHICS AND PUBLICATION MALPRACTICE IN THE JOURNALS OF THE NATIONAL ACADEMY OF SCIENCES OF THE REPUBLIC OF KAZAKHSTAN
}

For information on Ethics in publishing and Ethical guidelines for journal publication see http://www.elsevier.com/publishingethics and http://www.elsevier.com/journal-authors/ethics.

Submission of an article to the National Academy of Sciences of the Republic of Kazakhstan implies that the work described has not been published previously (except in the form of an abstract or as part of a published lecture or academic thesis or as an electronic preprint, see http://www.elsevier.com/postingpolicy), that it is not under consideration for publication elsewhere, that its publication is approved by all authors and tacitly or explicitly by the responsible authorities where the work was carried out, and that, if accepted, it will not be published elsewhere in the same form, in English or in any other language, including electronically without the written consent of the copyrightholder. In particular, translations into English of papers already published in another language are not accepted.

No other forms of scientific misconduct are allowed, such as plagiarism, falsification, fraudulent data, incorrect interpretation of other works, incorrect citations, etc. The National Academy of Sciences of the Republic of Kazakhstan follows the Code of Conduct of the Committee on Publication Ethics (COPE), and follows the COPE Flowcharts for Resolving Cases of Suspected Misconduct (http://publicationethics.org/files/u2/New Code.pdf). To verify originality, your article may be checked by the originality detection service Cross Check http://www.elsevier.com/editors/plagdetect.

The authors are obliged to participate in peer review process and be ready to provide corrections, clarifications, retractions and apologies when needed. All authors of a paper should have significantly contributed to the research.

The reviewers should provide objective judgments and should point out relevant published works which are not yet cited. Reviewed articles should be treated confidentially. The reviewers will be chosen in such a way that there is no conflict of interests with respect to the research, the authors and/or the research funders.

The editors have complete responsibility and authority to reject or accept a paper, and they will only accept a paper when reasonably certain. They will preserve anonymity of reviewers and promote publication of corrections, clarifications, retractions and apologies when needed. The acceptance of a paper automatically implies the copyright transfer to the National Academy of sciences of the Republic of Kazakhstan.

The Editorial Board of the National Academy of sciences of the Republic of Kazakhstan will monitor and safeguard publishing ethics.

Правила оформления статьи для публикации в журнале смотреть на сайте:

$$
\begin{gathered}
\text { www:nauka-nanrk.kz } \\
\text { social-human.kz }
\end{gathered}
$$

\author{
Редакторы М.С. Ахметова, Т.А. Апендиев, Д.С. Аленов \\ Верстка на компьютере А.М. Кульгинбаевой \\ Подписано в печать 10.10.2018 \\ Формат 60x881/8. Бумага офсетная. Печать - ризограф. \\ 11,6 п.л. Тираж 500. Заказ 5.
}

